\title{
Effects of Hydrogen Peroxide and Ultrasound on Biomass Reduction and Toxin Release in the Cyanobacterium, Microcystis aeruginosa
}

\section{Miquel Lürling ${ }^{1,2, *}$, Debin Meng ${ }^{1}$ and Elisabeth J. Faassen ${ }^{1}$}

1 Aquatic Ecology and Water Quality Management Group, Department of Environmental Sciences, Wageningen University, P.O. Box 47, 6700 AA Wageningen, The Netherlands;

E-Mails: mengdebin815@hotmail.com (D.M.); els.faassen@wur.nl (E.J.F.)

2 Department of Aquatic Ecology, Netherlands Institute of Ecology (NIOO-KNAW), P.O. Box 50, 6700 AB Wageningen, The Netherlands

* Author to whom correspondence should be addressed; E-Mail: miquel.lurling@wur.nl; Tel.: +31-317-483-898; Fax: +31-317-491-000.

External Editor: Elizabeth Hilborn

Received: 23 October 2014; in revised form: 25 November 2014 / Accepted: 3 December 2014 / Published: 10 December 2014

Abstract: Cyanobacterial blooms are expected to increase, and the toxins they produce threaten human health and impair ecosystem services. The reduction of the nutrient load of surface waters is the preferred way to prevent these blooms; however, this is not always feasible. Quick curative measures are therefore preferred in some cases. Two of these proposed measures, peroxide and ultrasound, were tested for their efficiency in reducing cyanobacterial biomass and potential release of cyanotoxins. Hereto, laboratory assays with a microcystin (MC)-producing cyanobacterium (Microcystis aeruginosa) were conducted. Peroxide effectively reduced $M$. aeruginosa biomass when dosed at 4 or $8 \mathrm{mg} \mathrm{L}^{-1}$, but not at 1 and $2 \mathrm{mg} \mathrm{L}^{-1}$. Peroxide dosed at 4 or $8 \mathrm{mg} \mathrm{L}^{-1}$ lowered total MC concentrations by $23 \%$, yet led to a significant release of MCs into the water. Dissolved MC concentrations were nine-times $\left(4 \mathrm{mg} \mathrm{L}^{-1}\right)$ and 12-times $\left(8 \mathrm{mg} \mathrm{L}^{-1} \mathrm{H}_{2} \mathrm{O}_{2}\right)$ higher than in the control. Cell lysis moreover increased the proportion of the dissolved hydrophobic variants, MC-LW and MC-LF (where $\mathrm{L}=$ Leucine, $\mathrm{W}=$ tryptophan, $\mathrm{F}=$ phenylalanine). Ultrasound treatment with commercial transducers sold for clearing ponds and lakes only caused minimal growth inhibition and some release of MCs into the water. Commercial ultrasound transducers are therefore ineffective at controlling cyanobacteria. 
Keywords: cyanotoxin; eutrophication control; lake restoration; LC-MS/MS; microcystin profile; PCC 7820

\section{Introduction}

Cyanobacterial proliferations and the formation of surface scums are among the most noticeable and malignant consequences of eutrophication [1]. Cyanobacterial blooms are a serious water quality threat, as blooms may produce nasty odors, cause high turbidity, anoxia, fish kills and food web alterations [2,3]. Furthermore, because cyanobacteria can produce a variety of potent toxins [4], cyanobacterial blooms exert strong pressure on important ecosystems services, such as recreation, aquaculture, irrigation and drinking water preparation. As a consequence, cyanobacterial blooms have severe economic impacts [5].

Because cyanobacterial blooms can deteriorate the water quality below the level that is needed for drinking water production, irrigation, industry, recreation and fishing, water managers try to control the massive development of cyanobacterial biomass. Nutrient reduction in the water body and its catchment area is clearly the most prominent effective approach to prevent cyanobacterial dominance [6]. However, reduction to sufficiently low nutrients loads may take fairly long to realize, and sometimes, it may not be feasible at all. Hence, in systems where the reduction of external nutrient loading is not economically feasible, effect-oriented (curative) measures may provide the most suitable nuisance control [7]. Such applications should be fast-acting and strongly reduce cyanobacteria biomass, so that safe water quality levels are rapidly reached [7]. In decision making for mitigating measures besides biomass also the production of cyanobacterial toxins are increasingly being taken into account [8], as these cyanotoxins make cyanobacterial blooms and surface scums a threat to environmental health and public safety $[9,10]$. While reducing biomass, care should be taken that the cyanobacterial toxins are not released into the water. Most cyanobacterial toxins are largely contained within the cyanobacterial cells, until lysis or damage of the cells liberates them [11,12]. Curative measures that result in the release of toxins from the cells, like the application of copper [13], endanger rather than improve water quality [4].

There are several promising curative measures to control cyanobacterial biomass. Copper is among the most applied algaecides [7], but toxicity issues using copper [4] have led to the promotion of hydrogen peroxide $\left(\mathrm{H}_{2} \mathrm{O}_{2}\right)$ as an effective non-toxic alternative [14,15]. Hydrogen peroxide is a powerful oxidizing agent that acts via the formation of hydroxyl radicals $(\cdot \mathrm{OH})$, which oxidize thiol groups in biomolecules [16]. However, it has been stated that the use of algaecides should be avoided, since it may lead to significant toxin release [4]. This finds some support in a whole lake experiment, in which both cyanobacteria biomass and the cyanotoxin microcystin (MC) strongly declined after application with $\mathrm{H}_{2} \mathrm{O}_{2}$, albeit with a two-days' time delay for $\mathrm{MC}$ [15], which might point towards a shift from particulate to dissolved MC and, thus, cyanotoxin release. A different technique that has been labelled as an "environmental friendly" or "green solution" to kill cyanobacteria is the use of ultrasound [17,18]. Nevertheless, a vast majority of studies on this subject have been performed with high power devices designed for cleaning and sterilizing that differ significantly from those sold on the 
market for controlling phytoplankton in lakes and ponds [19]. High power devices could lead to a strong increase in extracellular MC concentrations [20], but could also cause MC degradation [21,22] through peroxide formation and hydroxyl radicals [22]. The effect of commercially available ultrasound transducers on cyanobacterial toxin release is unknown. Thus, while both peroxide and ultrasound have been reported as promising measures in reducing cyanobacterial biomass, they consequently might cause a release of cyanotoxins.

Microcystins (MCs) are the most frequently occurring cyanotoxins. MCs are produced by a diverse range of cyanobacteria, of which Microcystis is one of the most common bloom formers [23-25]. MCs are non-ribosomal processed cyclic heptapeptides with a size between $909 \mathrm{Da}$ and $1115 \mathrm{Da}$ [26]. The general structure is cyclo(-D-ala-L- $X$-erythro- $\beta$-D-methylaspartic acid-L-Z-Adda-D-isoglutamic acid- $N$-methyldehydroalanine), where Adda is $(2 \mathrm{~S}, 3 \mathrm{~S}, 8 \mathrm{~S}, 9 \mathrm{~S})$-3-amino-9-methoxy-2,6,8-trimethyl-10phenyldeca-4,6-dienoic acid [27] (Figure 1). $X$ and $Z$ are variable L-amino acids contributing mostly to the dozens of variants of MCs that have been detected [27]. MCs are potent inhibitors of protein phosphatases, but the toxicity of different variants to mice varies substantially, where replacement of the hydrophobic leucine (L) in the first variable position with a hydrophilic amino acid (e.g., arginine, R) dramatically reduces toxicity [28] (Figure 1).

Figure 1. General structure of microcystins and examples of substitutions at position $X$ ( $\mathrm{L}=$ leucine, $\mathrm{R}=$ arginine $)$ and $Y(\mathrm{R}=$ arginine, $\mathrm{W}=$ tryptophan, $\mathrm{F}=$ phenylalanine $)$ resulting in the variants microcystin MC-RR, MC-LR, MC-LW and MC-LF, if positions $\mathrm{R} 1$ and $\mathrm{R} 2$ are methylated.

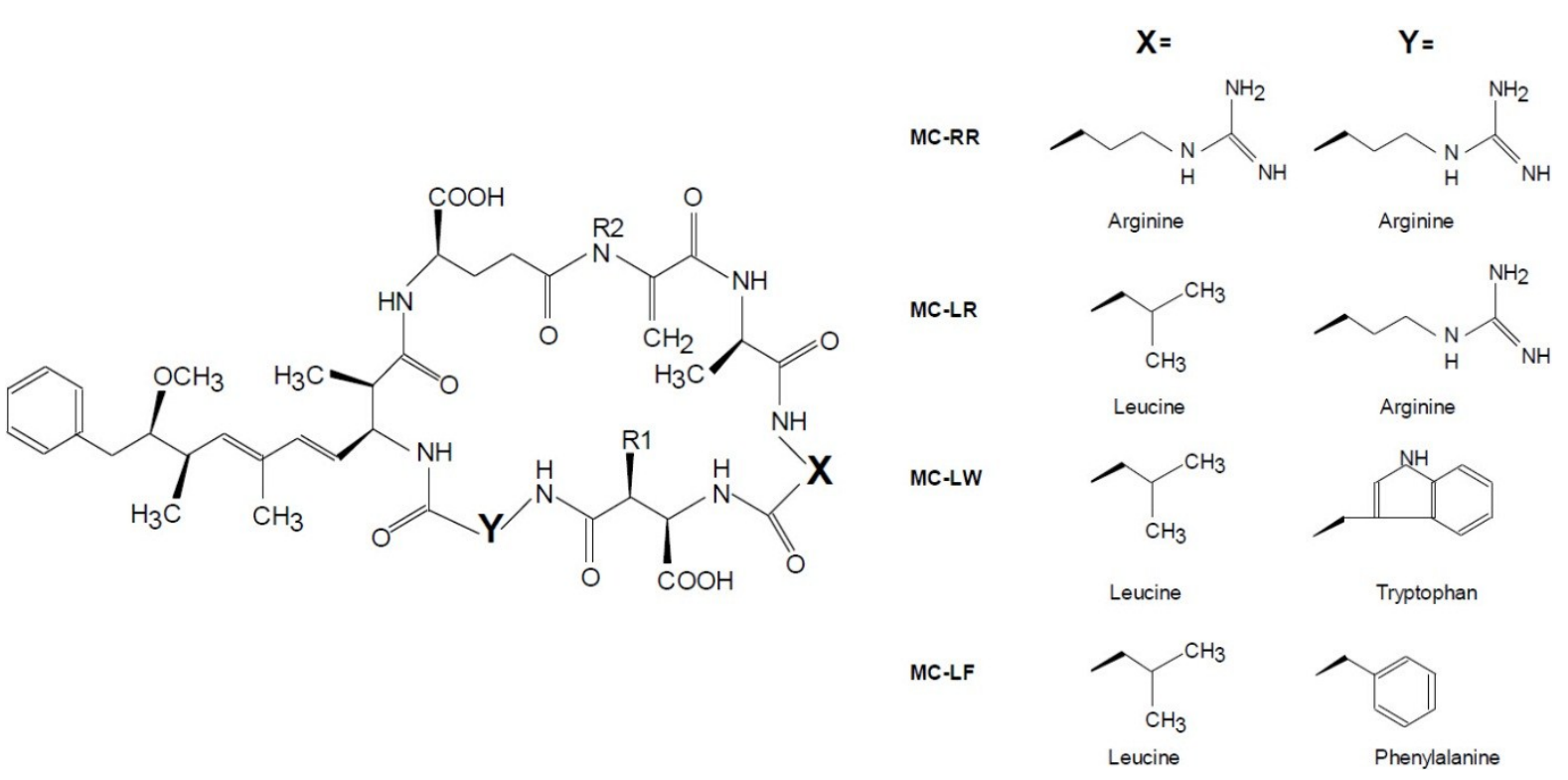

Little is known about how these different MC variants react to curative measures to control cyanobacterial biomass. The degradation rate of two MC variants (MC-LR and MC-RR, with $\mathrm{L}=$ Leucine and $\mathrm{R}=$ Arginine) upon irradiation with high power ultrasound (500 W, applied to a 22-mL reaction vessel) differed with an estimated EC50 of $30 \mathrm{~min}$ for MC-RR and $70 \mathrm{~min}$ for MC-LR [21]. However, the effect of commercially available ultrasound transducers on different MC variants has not been examined yet. Likewise, the few studies on $\mathrm{H}_{2} \mathrm{O}_{2}$ control of cyanobacteria that included MC analysis $[15,29,30]$ did not specify the effects on different MC variants. Therefore, in this study, 
we tested the hypothesis that both $\mathrm{H}_{2} \mathrm{O}_{2}$ treatment and ultrasound from commercial transducers sold for clearing lakes are effective at strongly reducing cyanobacteria biomass, without increasing the MC concentration in the water. Furthermore, we hypothesized that all measured MC variants reacted in a similar manner to these two treatments. Hereto, we ran laboratory experiments with a $M$. aeruginosa strain that, amongst others, produces the five MC variants: dm-7-MC-LR, MC-LR, MC-LY, MC-LF and MC-LW $(\mathrm{dm}=$ demethylated at position R2 in Figure 1: $\mathrm{R} 2=\mathrm{H})$.

\section{Results}

\subsection{Hydrogen Peroxide}

$\mathrm{H}_{2} \mathrm{O}_{2}$ application of 4 and $8 \mathrm{mg} \mathrm{L}^{-1}$ significantly lowered the cyanobacterial chlorophyll- $a$ and particle concentration after $24 \mathrm{~h}$ (Figure 2; Table 1). The chlorophyll- $a$ concentration was reduced to approximately $200 \mu \mathrm{g} \mathrm{L}^{-1}$ in the highest $\mathrm{H}_{2} \mathrm{O}_{2}$ treatments (Figure 2a), but the particle concentration was reduced to $\sim 9 \times 10^{4}$ particles $\mathrm{mL}^{-1}$ after $24 \mathrm{~h}$ in the $8-\mathrm{mg} \mathrm{L}^{-1} \mathrm{H}_{2} \mathrm{O}_{2}$ treatment (Figure 2c). The photosynthetic efficiency of the cyanobacteria, expressed as photosystem II efficiency (ФPSII), was more sensitive to $\mathrm{H}_{2} \mathrm{O}_{2}$ application; it was slightly reduced at 1 and $2 \mathrm{mg} \mathrm{L}^{-1}$, but became (virtually) zero at 4 and $8 \mathrm{mg} \mathrm{L}^{-1}$ (Figure 2b; Table 1). The $\mathrm{H}_{2} \mathrm{O}_{2}$ concentration at which $50 \%$ of the cyanobacteria were affected $\left(\mathrm{EC}_{50}\right)$ ranged from $2.5 \mathrm{mg} \mathrm{L}^{-1}$ for the photosynthetic efficiency, to $3.8 \mathrm{mg} \mathrm{L}^{-1}$ for cyanobacterial chlorophyll- $a$ (Table 1).

Table 1. Statistical information on the $\mathrm{H}_{2} \mathrm{O}_{2}$ experiment for three different endpoints: chlorophyll-a concentration (Chl- $a$ ), photosystem II efficiency (ФPSII) and particle concentration (\# $\mathrm{mL}^{-1}$ ) of Microcystis aeruginosa PCC 7820. Homogeneous subgroups were defined by a Tukey post hoc comparison at $p<0.05$ and are indicated by similar symbols $(a, b, c)$ per column.

\begin{tabular}{|c|c|c|c|c|c|c|}
\hline \multirow[t]{2}{*}{$\mathrm{H}_{2} \mathrm{O}_{2}$ treatment } & \multicolumn{2}{|c|}{ Chl-a $\left(\mu \mathrm{g} \mathrm{L^{-1 }}\right)$} & \multicolumn{2}{|c|}{$\Phi_{\text {PSII }}(-)$} & \multicolumn{2}{|c|}{ Particles (No. $\left.\mathrm{mL}^{-1}\right)$} \\
\hline & \multicolumn{6}{|c|}{ Tukey post hoc comparison } \\
\hline Control & \multicolumn{2}{|c|}{$\mathrm{a}$} & \multicolumn{2}{|c|}{$\mathrm{a}$} & \multicolumn{2}{|c|}{$\mathrm{a}$} \\
\hline $1 \mathrm{mg} \mathrm{L}^{-1}$ & \multicolumn{2}{|c|}{$\mathrm{a}$} & \multicolumn{2}{|c|}{$a, b$} & \multicolumn{2}{|c|}{$\mathrm{a}$} \\
\hline $2 \mathrm{mg} \mathrm{L}^{-1}$ & \multicolumn{2}{|c|}{$\mathrm{a}$} & \multicolumn{2}{|c|}{$\mathrm{b}$} & \multicolumn{2}{|c|}{$\mathrm{a}$} \\
\hline $4 \mathrm{mg} \mathrm{L}^{-1}$ & \multicolumn{2}{|c|}{$\mathrm{b}$} & \multicolumn{2}{|c|}{$\mathrm{c}$} & \multicolumn{2}{|c|}{$\mathrm{b}$} \\
\hline $8 \mathrm{mg} \mathrm{L}^{-1}$ & \multicolumn{2}{|c|}{$\mathrm{c}$} & \multicolumn{2}{|c|}{$\mathrm{c}$} & \multicolumn{2}{|c|}{$\mathrm{b}$} \\
\hline repeated measures ANOVA & $F$ & $p$ & $F$ & $p$ & $F$ & $p$ \\
\hline treatment effect $\left(F_{4,10}\right)$ & 367.5 & $<0.001$ & 284.1 & $<0.001$ & 102.4 & $<0.001$ \\
\hline time effect $\left(F_{3,30}\right)$ & 695.3 & $<0.001$ & 145.5 & $<0.001$ & 80.0 & $<0.001$ \\
\hline time $\times$ treatment interaction $\left(F_{12,30}\right)$ & 215.0 & $<0.001$ & 46.5 & $<0.001$ & 41.1 & $<0.001$ \\
\hline nonlinear regression & & $r^{2}$ adj & & $r^{2}$ adj & & $r^{2}$ adj \\
\hline $\mathrm{EC}_{50}\left(\mathrm{mg} \mathrm{H}_{2} \mathrm{O}_{2} \mathrm{~L}^{-1}\right)$ & 3.8 & 0.992 & 2.5 & 0.947 & 2.6 & 0.929 \\
\hline
\end{tabular}

MCs were determined at the start and after $24 \mathrm{~h}$ in the controls and the 1-, 4- and 8- $\mathrm{mg}_{2} \mathrm{O}_{2} \mathrm{~L}^{-1}$ treatments (Figure 3). Total MC concentrations (sum of dissolved and particulate MCs) were similar at the start of the experiment (one-way ANOVA, $F_{3,11}=3.23 ; p=0.082$ ), but after $24 \mathrm{~h}$, the total MC concentrations were lower in the $\mathrm{H}_{2} \mathrm{O}_{2}$-treated jars than in the controls $\left(F_{3,11}=13.5 ; p=0.002\right)$. 
The total MC concentrations in the highest $\mathrm{H}_{2} \mathrm{O}_{2}$ treatments had dropped 23 to $24 \%$ compared to their initial values (Figure 3).

Figure 2. (a) Chlorophyll- $a$ concentrations (CHL- $a, \mu \mathrm{g} \mathrm{L}{ }^{-1}$ ); (b) photosystem II efficiency (PSII); and (c) particle concentration (No. $\mathrm{mL}^{-1}$ ) of Microcystis aeruginosa PCC 7820 exposed to different $\mathrm{H}_{2} \mathrm{O}_{2}$ concentrations for $24 \mathrm{~h}$. Error bars indicate $1 \mathrm{SD}(n=3)$.
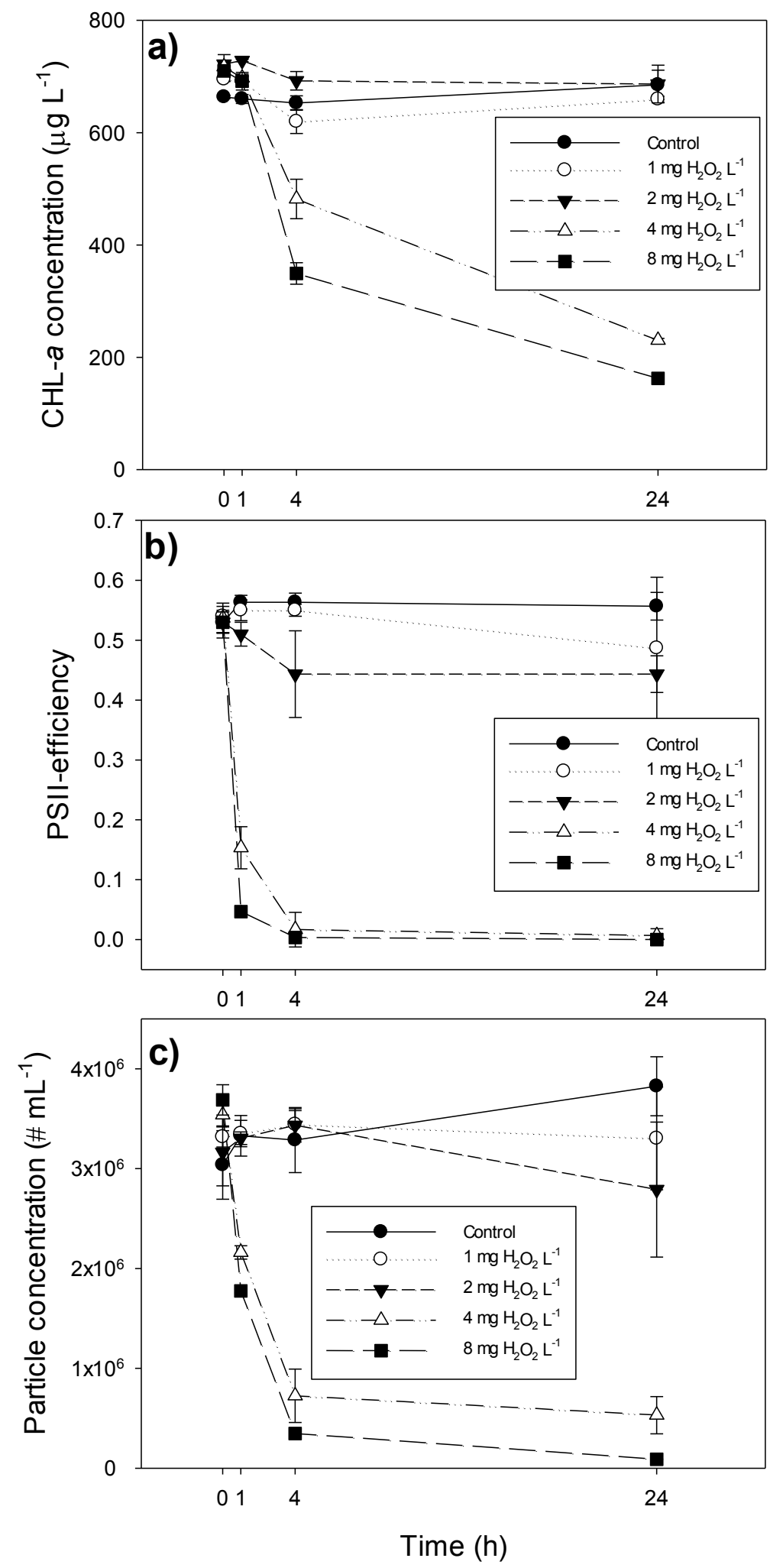
At the start of the experiment, on average, 6.0\% (SD 1.6\%) of the total MC pool consisted of dissolved MCs. After $24 \mathrm{~h}$, a similar percentage (6.5\%, SD 1.9\%) was found for the controls and the 1-mg $\mathrm{H}_{2} \mathrm{O}_{2} \mathrm{~L}^{-1}$ treatment, whereas in the 4- and 8- $\mathrm{mg} \mathrm{L}^{-1}$ treatments, the proportion of dissolved MCs had increased to $77 \%\left(4 \mathrm{mg} \mathrm{L}{ }^{-1}\right)$ and $85 \%\left(8 \mathrm{mg} \mathrm{L}^{-1}\right.$; Figure 3$) . \mathrm{H}_{2} \mathrm{O}_{2}$ application significantly increased the dissolved MC concentrations (one-way ANOVA; $F_{3,11}=408.9 ; p<0.001$ ): dissolved $\mathrm{MC}$ concentrations in the controls and the $1-\mathrm{mg} \mathrm{H}_{2} \mathrm{O}_{2} \mathrm{~L}^{-1}$ treatment were significantly lower than those in the 4- and 8- $\mathrm{mg} \mathrm{H}_{2} \mathrm{O}_{2} \mathrm{~L}^{-1}$ treatments (Holm-Sidak comparison, $p<0.05$ ).

Figure 3. Total particulate and dissolved microcystin (MC) concentrations $\left(\mu \mathrm{g} \mathrm{L}^{-1}\right)$ in Microcystis aeruginosa PCC 7820 at the start of the experiment (open bars) and after $24 \mathrm{~h}$ of exposure to different concentrations of hydrogen-peroxide $\left(\mathrm{H}_{2} \mathrm{O}_{2}\right.$, in $\mathrm{mg} \mathrm{L}^{-1}$; hatched bars). Error bars indicate $1 \mathrm{SD}(n=3)$. Similar symbols above the bars $(a, \alpha, \beta)$ indicate homogeneous groups of total MC concentrations that are not different at the $p=0.05$ level (Holm-Sidak comparison).

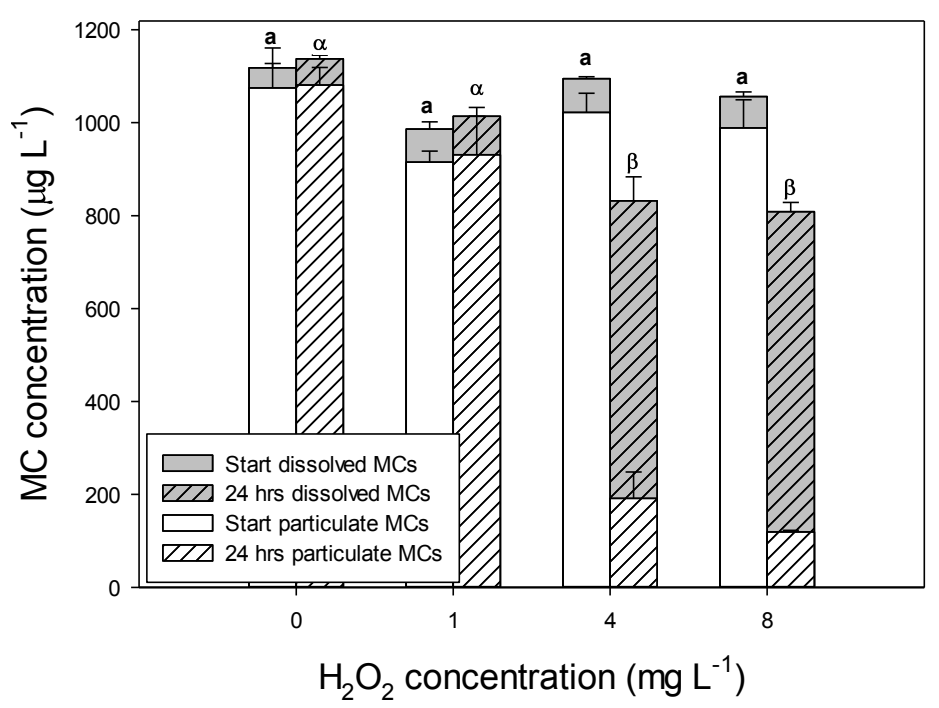

The composition of particulate MCs did not differ much during the experiment and between treatments (Figure 4a,b). MC-LR was the most abundant MC variant, making up on average $81 \%$ of the particulate MCs; MC-LF was present at 9\%, MC-LW at 5\% and dm-7-MC-LR at 3\%, and MC-LY was the least abundant variant with $2 \%$ abundance (Figure $4 a, b)$. The composition of the dissolved MCs at the start of the experiment deviated from the composition of particulate MCs (Figure 4a,c). This effect was strongest for the hydrophobic variant, MC-LW, which formed more than $5 \%$ of the particulate MCs, but only made up $0.6 \%$ of the dissolved MC pool at the start of the experiment (two-way ANOVA; $F_{1,23}=969.3 ; p<0.001$ ). Furthermore, the contribution of MC-LF, another hydrophobic variant, to the overall dissolved MC pool was reduced by half (to 4\%) compared to the particulate pool (Figure 4a,c). Here, two-way ANOVA not only indicated a significant difference between the contribution of dissolved MC-LF and particulate MC-LF to the overall MC pool $\left(F_{1,23}=969.3 ; p<0.001\right)$, but also revealed that in the dissolved pool, differences already appeared at the start of the experiment $\left(F_{3,23}=11.0 ; p<0.001\right)$ with dissolved MC-LF contributions of $3 \%$ in the control and the $1-\mathrm{mg} \mathrm{L}^{-1}$ treatment and $5 \%$ in the $4-$ and $8-\mathrm{mg} \mathrm{L}^{-1}$ treatments (Figure $4 \mathrm{c}$ ). At the end of the experiment, the proportion of dissolved MC-LW increased, particularly in the 4- and 8-mg $\mathrm{L}^{-1}$ 
$\mathrm{H}_{2} \mathrm{O}_{2}$ treatments. Furthermore, the proportion of dissolved MC-LF increased slightly in these treatments, at the expense of the proportion of the more hydrophilic MC-LR (Figure 4d). As a consequence, the dissolved $\mathrm{MC}$ profiles in the highest $\mathrm{H}_{2} \mathrm{O}_{2}$ treatments resembled the particulate $\mathrm{MC}$ profiles more than did the dissolved MC profiles of the control and the $1-\mathrm{mg} \mathrm{L}^{-1}$ treatment (Figure 4). Because MC-LW and MC-LF likely contribute more to the total MC toxicity than MC-LR, the dissolved MC pool of lysed cells was relatively more toxic than the dissolved pool of healthy cells.

Figure 4. Proportions of five microcystin (MC) variants in the particulate (a,b); and dissolved MC pools (c,d) of Microcystis aeruginosa PCC 7820 at the start of the experiment (start) and after $24 \mathrm{~h}$ of exposure to different concentrations of hydrogen-peroxide $\left(\mathrm{H}_{2} \mathrm{O}_{2}\right.$, in $\mathrm{mg} \mathrm{L}^{-1}$; end).
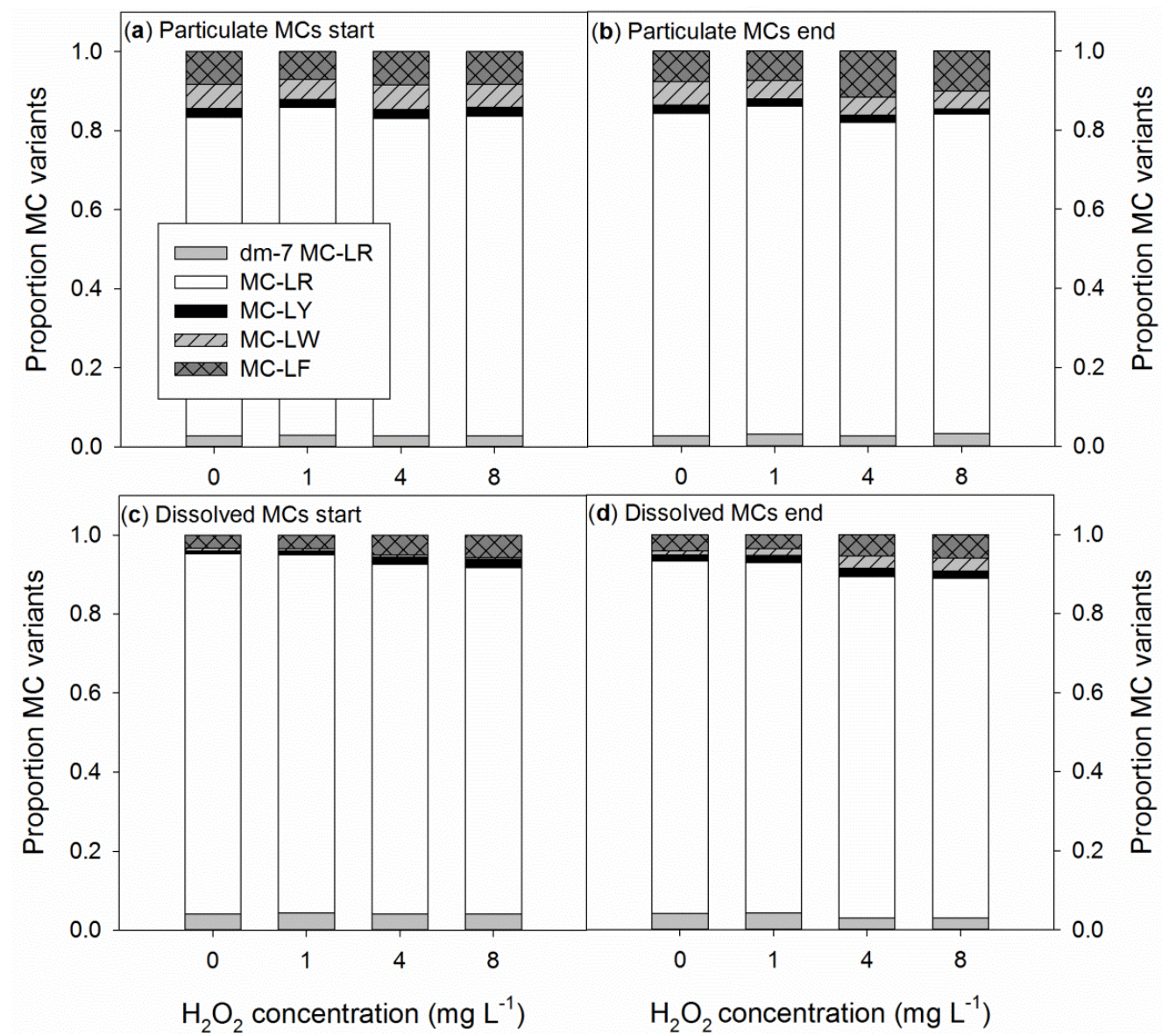

\subsection{Ultrasound}

Despite the application of ultrasound, chlorophyll- $a$ concentrations in both ultrasound treatments increased as strongly as the control treatment during the five-day course of the experiment (Figure 5; Table 2). The particle concentration, however, increased more in the control (2.3-times) than in the two ultrasound treatments (1.2-times; Figure 5c; Table 2). The $\Phi_{\text {PSII }}$ was slightly, but significantly, reduced by the ultrasound treatments, from an average of 0.56 (SD 0.01) in the controls during the five-day exposure period, to 0.53 (SD 0.01) in the AL-05 treatments and 0.52 (SD 0.02) in the AL-10 treatments (Figure 5b; Table 2). This effect was significant, because the within group variability was very low (Figure $5 b)$. 
Figure 5. (a) Chlorophyll- $a$ concentrations (CHL- $a, \mu \mathrm{g} \mathrm{L}{ }^{-1}$ ); (b) photosystem II efficiency (PSII); and (c) particle concentration (No. $\mathrm{mL}^{-1}$ ) in Microcystis aeruginosa PCC 7820 exposed to different ultrasound transducers (Flexidal AL-05 and AL-10) and in non-exposed control populations (control). Error bars indicate $1 \mathrm{SD}(n=3)$.
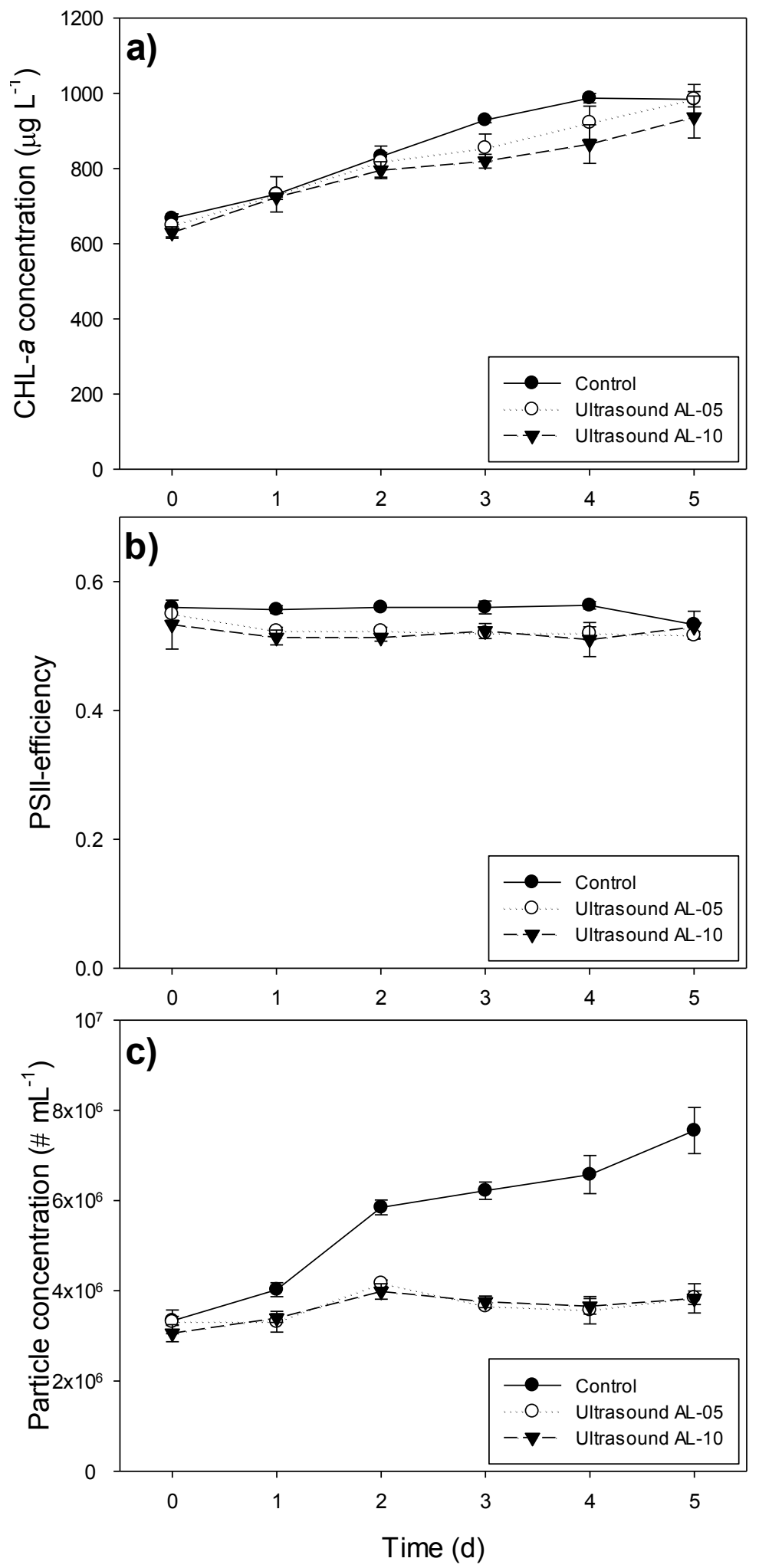
Table 2. Statistical information on the ultrasound experiment for three different endpoints: chlorophyll-a concentration (Chl-a), photosystem II efficiency (ФPSII) and particle concentration (\# $\mathrm{mL}^{-1}$ ) of Microcystis aeruginosa PCC 7820. Homogeneous subgroups were defined by a Tukey post hoc comparison at $p<0.05$.

\begin{tabular}{|c|c|c|c|c|c|c|}
\hline \multirow[t]{2}{*}{ Treatments } & \multicolumn{2}{|c|}{ Chl- $a\left(\mu \mathrm{g} \mathrm{L}^{-1}\right)$} & \multicolumn{2}{|c|}{$\Phi_{\text {PSII }}(-)$} & \multicolumn{2}{|c|}{ Particles (\# mL $\left.L^{-1}\right)$} \\
\hline & \multicolumn{6}{|c|}{ Tukey post hoc comparison } \\
\hline Control & \multicolumn{2}{|c|}{$\mathrm{a}$} & \multicolumn{2}{|c|}{$\mathrm{a}$} & \multicolumn{2}{|c|}{ a } \\
\hline AL-05 & \multicolumn{2}{|c|}{ a } & \multicolumn{2}{|c|}{ b } & \multicolumn{2}{|c|}{$\mathrm{b}$} \\
\hline AL-10 & \multicolumn{2}{|c|}{$\mathrm{a}$} & \multicolumn{2}{|c|}{$\mathrm{b}$} & \multicolumn{2}{|c|}{$\mathrm{b}$} \\
\hline repeated measures ANOVA & $F$ & $p$ & $F$ & $p$ & $F$ & $p$ \\
\hline treatment effect $\left(F_{2,6}\right)$ & 3.84 & 0.084 & 64.5 & $<0.001$ & 200.9 & $<0.001$ \\
\hline time effect $\left(F_{5,30}\right)$ & 423.3 & $<0.001$ & 2.35 & 0.065 & 103.8 & $<0.001$ \\
\hline time $\times$ treatment interaction $\left(F_{10,30}\right)$ & 5.61 & $<0.001$ & 1.56 & 0.169 & 42.9 & $<0.001$ \\
\hline
\end{tabular}

The effects of both transducers were similar; hence, only samples from the AL-05 treatments were analyzed for MCs. Total MCs significantly increased in the controls, from 1054 (SD 71) $\mu \mathrm{g} \mathrm{MC} \mathrm{L} \mathrm{g}^{-1}$ at the start to 1558 (SD 110) $\mu \mathrm{g} \mathrm{MC} \mathrm{L}^{-1}$ at the end of the experiment ( $t$-test; $t=6.67 ; p=0.003$; Figure 6). The ultrasound treatment caused no decline in total MCs as total concentrations at the start (1023 SD $\left.11 \mu \mathrm{g} \mathrm{MC} \mathrm{L}{ }^{-1}\right)$ and after five days (1079 SD $\left.34 \mu \mathrm{g} \mathrm{MC} \mathrm{L}^{-1}\right)$ were similar $(t=2.68$; $p=0.055)$. The proportion of dissolved MCs after five days was significantly higher in the ultrasound treatments $(19 \%)$ than in the controls $(5 \%, t=6.17 ; p=0.004$, Figure 6$)$.

Figure 6. Particulate and dissolved microcystin (MC) concentrations $\left(\mu \mathrm{g} \mathrm{L}^{-1}\right)$ in non-exposed (open bars) and ultrasound (Flexidal AL-05)-exposed Microcystis aeruginosa PCC 7820 (hatched bars). Error bars indicate $1 \mathrm{SD}(n=3)$.

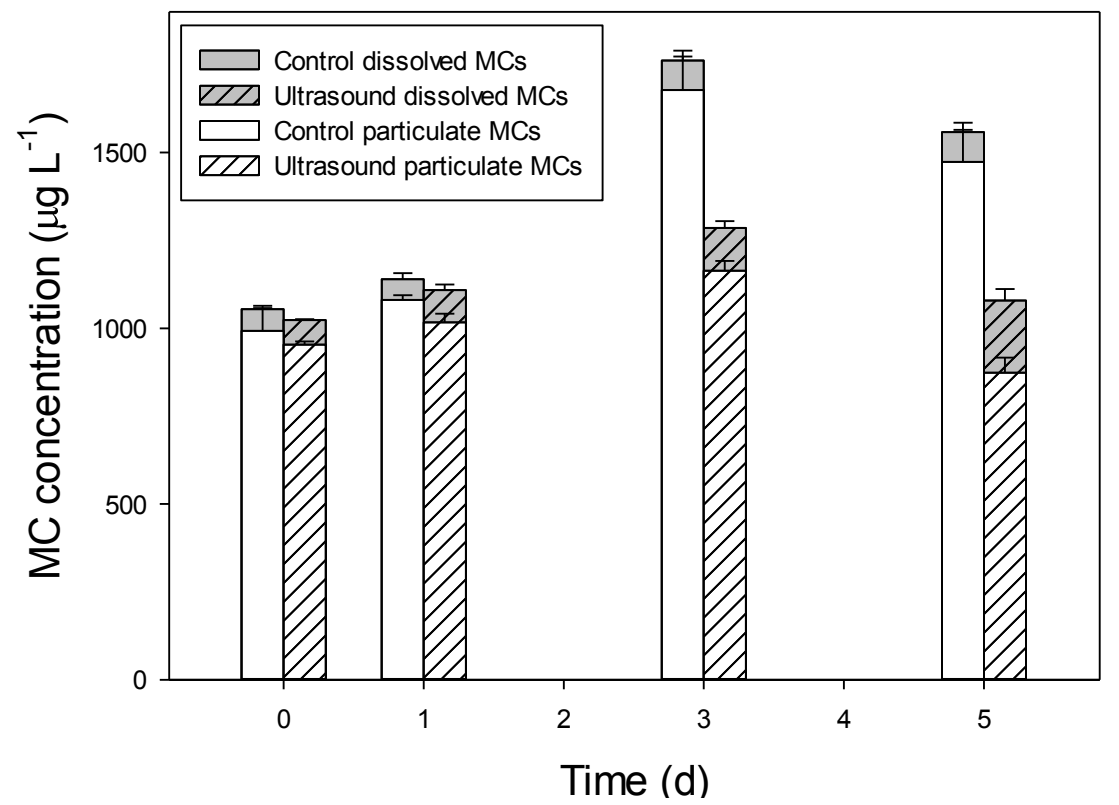

The composition of particulate MCs was similar during the course of the experiment in both controls and ultrasound treatments (Figure 7a,b) and resembled the particulate MC composition of the $\mathrm{H}_{2} \mathrm{O}_{2}$ experiment. Furthermore, the composition of dissolved MCs was similar in controls and the 
ultrasound treatments and remained stable during the experiment (Figure 7c,d). However, the composition of the dissolved MCs deviated slightly from the composition of particulate MCs (Figure 7). Two-way repeated-measures ANOVA revealed a significantly higher contribution of $\mathrm{dm}-7-\mathrm{MC}-\mathrm{LR}$ in the dissolved MCs (4\%) than in the particulate MC pool (3\%). Likewise, MC-LR was significantly more abundant in the dissolved pool (85\%) than in the particulate MC pool $(81 \%$; $\left.F_{1,8}=124.9 ; p<0.001\right)$. MC-LY was present in similar proportions in both the dissolved and particulate MCs $\left(2 \% ; F_{1,8}=4.0 ; p=0.080\right)$, while MC-LW $\left(F_{1,8}=2311 ; p<0.001\right)$ and MC-LF $\left(F_{1,8}=65.6 ; p<0.001\right)$ were significantly less abundant in the dissolved MC pool $(4 \% \mathrm{MC}-\mathrm{LW}$ and $5 \% \mathrm{MC}-\mathrm{LF}$ ) than in the particulate MC pool, where they made up 6\% (MC-LW) and 8\% (MC-LF).

Figure 7. Course of the proportions of five microcystin (MC) variants in the particulate $(\mathbf{a}, \mathbf{b})$ and dissolved MC pools (c,d) of non-exposed Microcystis aeruginosa PCC 7820 populations (control) and populations exposed to ultrasound from Flexidal AL-05 transducers (ultrasound).
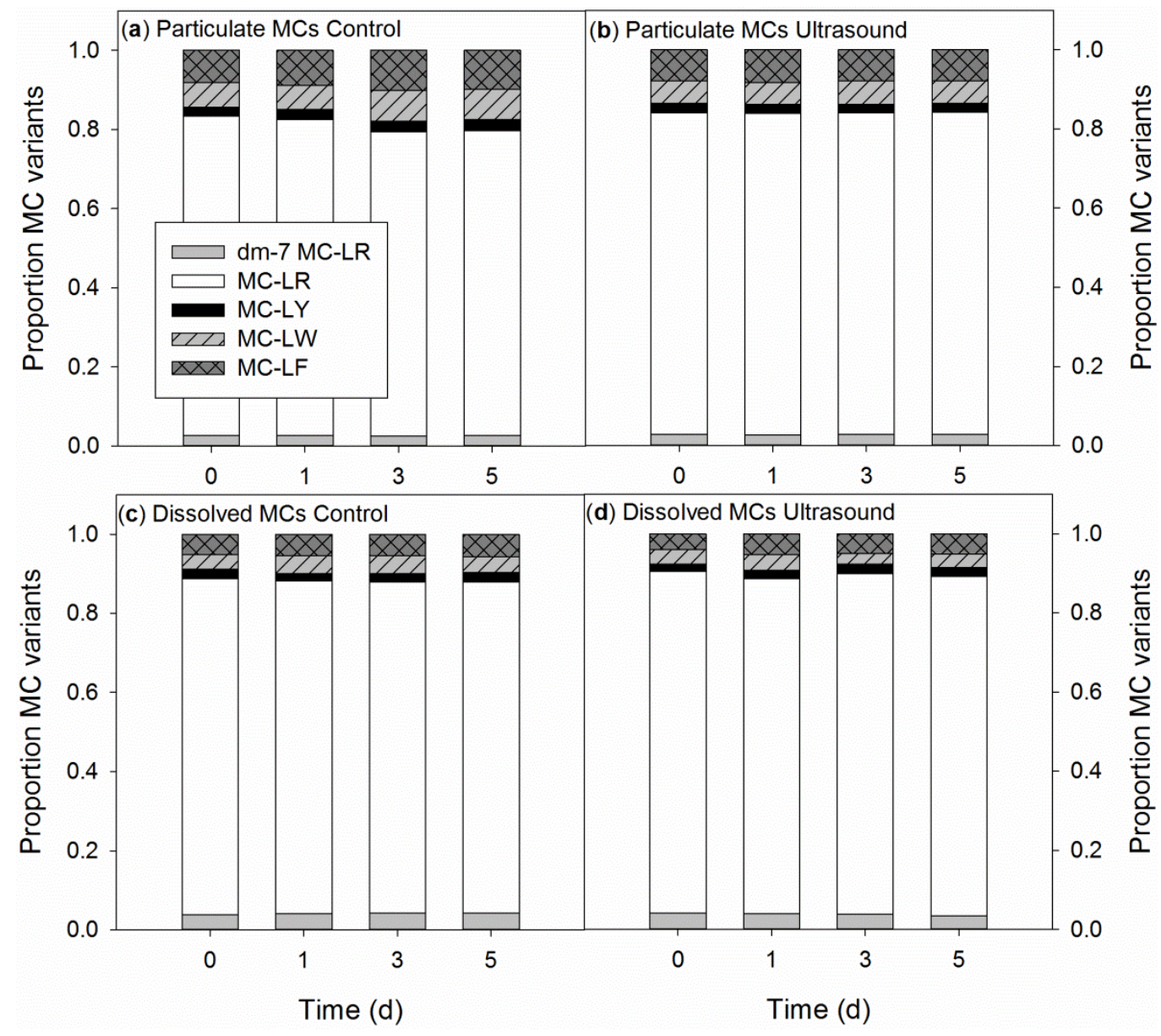

\section{Discussion}

\subsection{Hydrogen Peroxide}

$\mathrm{H}_{2} \mathrm{O}_{2}$ effectively reduced $M$. aeruginosa biomass when dosed at 4 or $8 \mathrm{mg} \mathrm{L}^{-1}$, but not at 1 and $2 \mathrm{mg} \mathrm{L}{ }^{-1}$. Hence, the $\mathrm{EC}_{50}$, depending on the endpoint, was between 2.5 and $3.8 \mathrm{mg}_{2} \mathrm{O}_{2} \mathrm{~L}^{-1}$ under our experimental conditions, which is a little higher than an $\mathrm{EC}_{50}$ of $0.3-0.5 \mathrm{mg} \mathrm{L}^{-1}$ reported for 
another strain of $M$. aeruginosa [31,32] and the dose of $2 \mathrm{mg} \mathrm{H}_{2} \mathrm{O}_{2} \mathrm{~L}^{-1}$ that was applied to a Planktothrix agardhii-dominated lake in The Netherlands, and removed $99 \%$ of the cyanobacteria [15]. However, in other field trials, $30 \%-40 \%$ of the cyanobacteria remained after an $\mathrm{H}_{2} \mathrm{O}_{2}$ treatment, despite the fact that dosages of 40 to $95 \mathrm{mg} \mathrm{H}_{2} \mathrm{O}_{2} \mathrm{~L}^{-1}$ were used [29,33]. For field collected colonial M. aeruginosa, a relatively high $\mathrm{EC}_{50}$ of about $30 \mathrm{mg} \mathrm{H}_{2} \mathrm{O}_{2} \mathrm{~L}^{-1}$ was found [34]. This high EC50 could have resulted from the use of extremely high cyanobacteria concentrations [34]. Alternatively, the mucilaginous colonies, often with quite a few bacteria attached [35], might provide M. aeruginosa cells protection against $\mathrm{H}_{2} \mathrm{O}_{2}$. Our strain of $M$. aeruginosa was uni- and bi-cellular; a normal growth form under laboratory conditions, but contrasting to its typical colonial appearance in the field [36]. Where an $\mathrm{H}_{2} \mathrm{O}_{2}$ concentration of $4 \mathrm{mg} \mathrm{L}^{-1}$ was sufficient to strongly reduce our strain, when blooms of colonial Microcystis are the target, higher concentrations may be needed. This might be a drawback in nature protection sites, as those $\mathrm{H}_{2} \mathrm{O}_{2}$ concentrations also may have an effect on non-target organisms, such as zooplankton $[15,29,37]$.

The $M$. aeruginosa biomass reduction was probably a result of the loss of membrane integrity, followed by cell lysis [38,39]. Consequently, cell contents and cyanotoxins could be released upon treatment with $\mathrm{H}_{2} \mathrm{O}_{2}$. For instance, leakage of phycobiliproteins into the water after $\mathrm{H}_{2} \mathrm{O}_{2}$ exposure is reflected in Wang et al. [34], where a blue color at higher $\mathrm{H}_{2} \mathrm{O}_{2}$ dose(s) is clearly visible in their Figure 3. In our experiment, relatively high chlorophyll- $a$ concentrations were present in the $8-\mathrm{mg} \mathrm{L}^{-1}$ $\mathrm{H}_{2} \mathrm{O}_{2}$ treatment after $24 \mathrm{~h}$, while the particle concentration at that time had dropped to only $2.4 \%$ of the number of particles at the start of the experiment. Furthermore, after $24 \mathrm{~h}$, dissolved MC concentrations in the 1-, 4- and 8-mg L ${ }^{-1}$ treatments had increased respectively 1.4-, 8.9- and 12-times compared to the control, which confirms compromised membrane integrity and leakage of cell contents. Similarly, lysis of cyanobacterial cells led to the appearance of dissolved MCs in the first few days after an $\mathrm{H}_{2} \mathrm{O}_{2}$ application in a waste water stabilization pond [29]. Some evidence for the release of MCs is also found in the field application of Matthijs et al. [15], where the MC decline was similar to the cyanobacterial biomass decline, but with a two-day delay. In contrast, a laboratory study using relatively high $\mathrm{H}_{2} \mathrm{O}_{2}$ concentrations $\left(10.2-102 \mathrm{mg} \mathrm{L}^{-1}\right)$ found no increase in dissolved MCs after the $\mathrm{H}_{2} \mathrm{O}_{2}$ treatments, which was attributed to the degradation of MCs [30]. In our experiment, we found indications that part of the MCs was also lost, as after $24 \mathrm{~h}$, the sum of dissolved and particulate MCs in the 4- and $8-\mathrm{mg} \mathrm{L}^{-1}$ treatments were $23 \%$ lower than at the start of the experiment. As proposed by Song et al. [22], the degradation pathway is probably by hydroxyl radical attack on the Adda benzene ring, causing ring hydroxylation and subsequent oxidative cleavage of the Adda structure.

At the start, and after $24 \mathrm{~h}$ in the control and $1-\mathrm{mg} \mathrm{L}^{-1}$ treatments, the dissolved MCs contributed $6 \%-6.5 \%$ to the overall MC pool. This is in agreement with literature reports that most of the total detectable toxin pool is intracellular in healthy growing cells [40-42]. The intracellular MC composition in our study is in line with findings of others; MC-LR is the most abundant MC variant in M. aeruginosa PCC 7820, but its relative contribution might vary (Table 3). Variation in MC variant expression might be caused by different growth conditions (e.g., [43]). However, the difference between the intracellular and extracellular MC profiles in healthy cells observed in both of our experiments (Figures 4 and 7) might point towards differences in terms of membrane crossing [44] or to different adsorption characteristics. We observed lower proportions of the more hydrophobic variants, MC-LW and MC-LF, in the dissolved fraction than in the particulate fraction of healthy cells. 
This difference can probably be attributed to a higher adsorption of the more hydrophilic variants on living cells. Although MCs do not easily adsorb on sediments or on suspended particulate matter [41], the more hydrophobic variants, MC-LW and MC-LF, were more associated with lipids in monolayer experiments than was the more hydrophilic MC-LR [45]. Adsorption of more hydrophobic MCs on remaining cells seems a more likely explanation than a passive diffusion mechanism [44], as that would result in a relatively higher proportion of hydrophobic MCs, as these diffuse more easily across the membrane. When most cells were lysed in the 4- and 8-mg $\mathrm{H}_{2} \mathrm{O}_{2} \mathrm{~L}^{-1}$ treatments, the proportions of the dissolved hydrophobic MCs increased (Figure 4d).

Table 3. The relative proportion (\%) of different intracellular microcystin (MC) variants in Microcystis aeruginosa PCC 7820.

\begin{tabular}{cccc}
\hline MC-variant & Our study & Ríos et al. [46] & Robillot et al. [44] \\
\hline MC-LR & 81.2 & 79.5 & 51.0 \\
MC-LY & 2.2 & 1.6 & 8.6 \\
MC-LF & 8.0 & 0.6 & 19.4 \\
MC-LW & 5.8 & 1.0 & 21.0 \\
others & 2.8 & 17.3 & - \\
\hline
\end{tabular}

In the high $\mathrm{H}_{2} \mathrm{O}_{2}$ doses, total $\mathrm{MC}$ concentrations were about $23 \%$ reduced, but an $\mathrm{H}_{2} \mathrm{O}_{2}$ dose needed to oxidize all released MCs to levels below the WHO guideline of $1 \mu \mathrm{g} \mathrm{L^{-1 }}$ would imply negative effects on non-target organisms, such as large bodied cladocerans. For example, LC50 values of 5-6 mg $\mathrm{H}_{2} \mathrm{O}_{2} \mathrm{~L}^{-1}$ for Daphnia and $2 \mathrm{mg} \mathrm{L}^{-1}$ for Moina have been reported [37]. Increased mortality for Daphnia was observed at $\mathrm{H}_{2} \mathrm{O}_{2}$ concentrations exceeding $3 \mathrm{mg} \mathrm{L}^{-1}$; for Moina, this occurred already at concentrations exceeding $1 \mathrm{mg} \mathrm{H}_{2} \mathrm{O}_{2} \mathrm{~L}^{-1}$ [29,37], while in enclosures, cladocerans were affected by $\mathrm{H}_{2} \mathrm{O}_{2}$ concentrations exceeding $2.5 \mathrm{mg} \mathrm{L}^{-1}$ [15]. In our study, more than $75 \%$ of the MCs remained present, even when a $\mathrm{H}_{2} \mathrm{O}_{2}$ dose of $8 \mathrm{mg} \mathrm{L}^{-1}$ was applied. This implies that algicides should be avoided as much as possible, because a sudden increase in dissolved MC concentrations might present a health hazard to livestock and humans using the water for consumption [11] and could potentially affect aquatic organisms that would not readily ingest cyanobacteria (e.g., [47]).

\subsection{Ultrasound}

Ultrasound can have detrimental effects on cyanobacteria; it can cause gas vesicle collapse, cell wall disruption and disturbance of photosynthetic activity $[17,18]$. Several commercial suppliers state that their "environmental-friendly" ultrasound transducers will kill cyanobacteria rapidly [48]. However, the low power used by these commercially available transducers, in contrast to the high power cavitation-producing transducers in some laboratory settings, puts strong constraints on their efficacy [19]. Indeed, our study confirmed the findings of Lürling and Tolman [19,49] that commercial ultrasound transducers do not remove cyanobacteria. In our experiment with $M$. aeruginosa, ultrasound somewhat impaired cyanobacterial growth, but the transducer was only placed in a small volume $(800 \mathrm{~mL})$. When applied in larger volumes, significantly less power will be transmitted, and consequently, the impact on cyanobacteria will be far lower when such transducers are employed in ponds and lakes [18], as recommended by the manufacturer [11]. Likewise, the marginal damage to the 
cyanobacterial cells, reflected by the small increase in dissolved MCs, will be less in larger volumes. In addition, possible direct effects of ultrasound on $\mathrm{MC}$ degradation will be less in large volumes, as MC degradation is proportional to the power and duration of ultrasound [21]. Intensities used to degrade MCs are much higher than the ones employed in our study. For instance, Song et al. [22] used $22.7 \mathrm{~W} \mathrm{~mL}^{-1}$ to degrade MCs, while the intensity used in our experiment was $7.9 \times 10^{-4} \mathrm{~W} \mathrm{~mL}^{-1}$. High intensity ultrasound devices cause acoustic cavitation: a process in which compression and rarefaction create gas bubbles that may collapse [50]. On collapse of the bubbles, formation of radicals and hydrogen peroxide production may lead to degradation of MCs [22]. However, the power of the transducers applied in our study is probably insufficient to cause cavitation [19], and hence, strong ultrasound induced degradation of MCs was not observed; ultrasound caused no decline in total MCs, as total concentrations at the start of the experiment and after five days were similar.

Using high power devices to clear surface waters from cyanobacteria is not recommended, because the energy needed to treat lakes and ponds is very high, and non-target organisms will be damaged. For instance, ultrasound is used to disinfect ballast water or raw water for drinking water preparation, where it may inactivate motile plankton [51] or kill zooplankton, especially larger cladocerans [52]. Ultrasound caused cell damage in the macrophyte, Elodea, and in fruit flies [53]. Moreover, the commercial ultrasound transducers, as the ones we have used in our study, resulted in rapid death of the zooplankton grazer, Daphnia [49]. Therefore, ultrasound should not be considered "environmental friendly" [18] or a "green solution" [17] to control cyanobacteria blooms.

Some studies have reported ultrasound-induced cyanobacterial filament shortening by breakage and cell lysis at the break points $[19,54]$. This could lead to the release of toxins in the water. Our strain of M. aeruginosa was completely uni- and bi-cellular. However, in the field, M. aeruginosa grows mostly as large colonies, embedded in mucous. There is a possibility that application of commercial ultrasound devices could break natural colonies into smaller fragments, but no major impact, such as on toxin release, is expected.

The composition of the MC pools was not influenced by the ultrasound and the MC profiles remained similar during the experiment. The only difference was between the composition of the dissolved MC pool and the particulate MC pool that showed less hydrophobic MC-LW and MC-LF in the dissolved pool than in the particulate one, as had also been observed in the $\mathrm{H}_{2} \mathrm{O}_{2}$ experiment.

\subsection{Overall}

In this study, we simulated heavy bloom concentrations of $M$. aeruginos $a\left(\approx 700 \mu\right.$ g chlorophyll- $\left.a \mathrm{~L}^{-1}\right)$ and treated them with $\mathrm{H}_{2} \mathrm{O}_{2}$ and ultrasound from commercial transducers. Where doses of 4 to $8 \mathrm{mg} \mathrm{H}_{2} \mathrm{O}_{2} \mathrm{~L}^{-1}$ were sufficient to kill $M$. aeruginosa, MC concentrations in the water remained high, and the majority of the particulate MCs became dissolved. The high cyanobacteria concentrations we used are not uncommon in urban ponds in The Netherlands [55], or elsewhere (e.g., [56-59]), and even higher concentrations are common in surface scums in ponds and lakes. Treating such blooms (and scums) with $\mathrm{H}_{2} \mathrm{O}_{2}$ may only be feasible if $P$. agardhii is the dominant species [60], but with $M$. aeruginosa dominating, it is not recommended, as the relatively high $\mathrm{H}_{2} \mathrm{O}_{2}$ concentrations needed for an effective treatment might harm non-target organisms and might cause a release of cell contents, including toxins and nutrients, which may fuel a subsequent bloom. Moreover, as previously reported $[29,34], \mathrm{H}_{2} \mathrm{O}_{2}$ 
treatment may result in surface accumulation of affected cyanobacterial cells. Such accumulation of decaying material will in itself cause nuisance and reduce water quality.

Ultrasound from the commercial available transducers was not effective at clearing a small volume of $800 \mathrm{~mL}$ of a cyanobacterial suspension. Hence, these devices will not be effective in larger volumes, which is in line with additional laboratory experiments [19], a tank experiment [49] and a few lake-scale experiments where ultrasound appeared ineffective at mitigating cyanobacteria nuisance [61,62]. Consequently, the application of ultrasound is not a suitable way to reduce cyanobacterial biomass.

Water authorities should perform a system analysis to determine the flow of water and sources of nutrients in systems suffering from blooms, after which the most promising set of mitigating measures can be selected. Here, source-oriented measures principally targeting the phosphorus inflow and internal loading remain essential for reducing eutrophication. However, in situations where source-oriented measures are not easily achievable, cost-effective end-of-pipe solutions might be an alternative, but these should have been proven to be effective in situ. For instance, coagulants in combination with a ballast can effectively precipitate positively buoyant cyanobacteria out of the water column as intact cells $[63,64]$ without releasing cell contents and, thereby, nutrients and toxins $[65,66]$.

\section{Experimental Section}

\subsection{Organisms}

The cyanobacterium, Microcystis aeruginosa (Kützing) Kützing strain PCC 7820, was obtained from the Pasteur Culture Collection (Paris, France). The culture was maintained in 250-mL Erlenmeyer flasks that contained $100 \mathrm{~mL}$ sterile modified WC (Woods Hole modified CHU10) medium [67] and were closed with a cellulose stopper. The flasks were placed at $25{ }^{\circ} \mathrm{C}$ in $40 \mu \mathrm{mol}$ quanta $\mathrm{m}^{-2} \mathrm{~s}^{-1}$ provided in a 14:10 h light-dark cycle. Stock cultures were transferred to fresh medium every two to three weeks. These stocks were used to inoculate twenty 2-L Erlenmeyer flasks with $1.7 \mathrm{~L}$ sterile WC-medium to produce sufficient biomass for the experiments. The 2-L flasks were placed in a conditioned climate room at $23{ }^{\circ} \mathrm{C}$ in a $12: 12 \mathrm{~h}$ light dark cycle at a light intensity of $100 \mu \mathrm{mol}$ quanta $\mathrm{m}^{-2} \mathrm{~s}^{-1}$. The flasks were shaken manually once a day. Regularly, a 2-mL subsample was taken for chlorophyll- $a$ determination by a PHYTO-PAM phytoplankton analyzer (Heinz Walz $\mathrm{GmbH}$, Effeltrich, Germany). Experiments were started with the cultured material once the chlorophyll- $a$ concentration was $600-800 \mu \mathrm{g} \mathrm{L}^{-1}$ (equivalent to cell concentrations of on average $3.8 \times 10^{6}$ cells mL ${ }^{-1} \mathrm{SD} 0.3 \times 10^{6}$ cells $\mathrm{mL}^{-1}$ ). Hereto, aliquots of $800 \mathrm{~mL}$ cultured $M$. aeruginosa were transferred from the 2-L flasks to experimental glass jars (1 L volume). The remaining cultures in the 2-L Erlenmeyer's were replenished with fresh, sterile WC-medium and placed back for further culturing. The experiments were conducted at $23{ }^{\circ} \mathrm{C}$ in $100 \mu \mathrm{mol}$ quanta $\mathrm{m}^{-2} \mathrm{~s}^{-1}$ light intensity with 12:12 h light-dark cycle in a conditioned climate room.

\subsection{Hydrogen Peroxide}

At the start of the experiment, suspensions of $M$. aeruginosa in WC-medium were evenly distributed over 15 replicate 1-L jars such that each contained $800 \mathrm{~mL}$ suspension with a chlorophyll- $a$ concentration of 702 (SD 23) $\mu \mathrm{g} \mathrm{L} \mathrm{L}^{-1}$. Hydrogen peroxide $\left(\mathrm{H}_{2} \mathrm{O}_{2} 30 \%, 1.07209 .0500\right.$, Merck KGaA, 
Darmstadt, Germany) was added in triplicate to the jars in concentrations of $0,1,2,4$ and $8 \mathrm{mg} \mathrm{L}^{-1}$. $\mathrm{H}_{2} \mathrm{O}_{2}$ was gently added under continuous stirring. The jars were sealed with Parafilm with a small opening for ventilation and sampling. At $0,1,4$ and $24 \mathrm{~h}$, MC samples ( $8 \mathrm{~mL}$, stored in glass bottles) and samples for chlorophyll- $a$ and cell density measurements $(10 \mathrm{~mL})$ were taken from the middle of the jar after mixing with a glass stick. Cyanobacterial chlorophyll- $a$ concentrations and photosystem II efficiency were measured directly after sampling by a PHYTO-PAM phytoplankton analyzer; particle concentrations were measured by an electronic particle counter (CASY cell counter, Schärfe System $\mathrm{GmBh}$, Reutlingen, Germany) with a range from 1 to $120 \mu \mathrm{m}$ equivalent spherical diameter. MCs were determined as outlined below (Section 4.4).

\subsection{Ultrasound}

Seven ultrasound devices (three of type AL-05 and four of type AL-10, Flexidal BVBA, Aalter, Belgium) were purchased commercially. All ultrasound transducers produced block waves at frequencies of $\sim 20 \mathrm{kHz}, \sim 28 \mathrm{kHz}$ and $\sim 44 \mathrm{kHz}$. The acoustic power of the transducers was $0.63 \mathrm{~W}$ (SD 0.05, $n=3$ ) for AL-05 transducers [49] and $0.68 \mathrm{~W}$ (SD 0.23, $=4$ ) for the AL-10 transducers [19].

At the start of the experiment, suspensions of $M$. aeruginosa in WC-medium were evenly distributed over 9 replicate 1-L jars, such that each contained an $800-\mathrm{mL}$ suspension with a chlorophyll- $a$ concentration of 649 (SD 24) $\mu \mathrm{g} \mathrm{L} \mathrm{L}^{-1}$. In three jars, AL-05 transducers were placed $2 \mathrm{~cm}$ below the water surface; in three other jars, AL-10 transducers were placed at a similar depth; while three jars remained untreated (controls). The ultrasound transducers operated incessantly during the experiment for 5 days. Sub-samples of $10 \mathrm{~mL}$ for chlorophyll- $a$, photosystem II efficiency and cell density analysis (electronic particle counter) were taken daily during the experiment (Days 0 to 5) after mixing with a glass stick. MC samples ( $8 \mathrm{~mL}$ stored in glass bottles) were taken from the water column after mixing at $0,1,3$ and 5 days. MCs were determined as outlined below (Section 4.4).

\subsection{Analysis}

The 8-mL MC samples were filtered through glass-fiber filters (Whatman $\mathrm{GF} / \mathrm{C}$, Whatman International Ltd., Maidstone, UK). Of each sample, the filtrate was collected in clean 8-mL glass tubes, while the filters were rolled gently and placed in another 8-mL glass tube. Both the filtrate and the filter samples were dried in a Speedvac (Thermo Scientific Savant SPD121P, Waltham, MA, USA), after which the filters were extracted three times at $60{ }^{\circ} \mathrm{C}$ in $2.5 \mathrm{~mL} 75 \%$ methanol-25\% Millipore water $(v / v)$. The extracts were dried in the Speedvac and subsequently reconstituted in $800 \mu \mathrm{L}$ methanol, as were the dried filtrates. The reconstituted samples were transferred to 2-mL Eppendorf vials with a cellulose-acetate filter $(0.2 \mu \mathrm{m}$, Grace Davison Discovery Sciences, Deerfield, IL, USA) and centrifuged for $5 \mathrm{~min}$ at $16,000 \times g$ (VWR Galaxy 16DH, VWR International, Buffalo Grove, IL, USA). Filtrates were transferred to amber glass vials for LC-MS/MS analysis.

Samples were analyzed for eight MC variants (dm-7-MC-RR, MC-RR, MC-YR, dm-7-MC-LR, MC-LR, MC-LY, MC-LW and MC-LF) and nodularin (NOD) by LC-MS/MS, as described in [68]. LC-MS/MS analysis was performed on an Agilent $1200 \mathrm{LC}$ and an Agilent 6410A QQQ. The compounds were separated on an Agilent Eclipse XDB-C18 $4.6 \times 150 \mathrm{~mm}, 5-\mu \mathrm{m}$ column by Millipore water with $0.1 \%$ formic acid ( $v / v$, Eluent A) and acetonitrile with $0.1 \%$ formic acid $(v / v$, Eluent B). 
The elution program was 0-2 min 30\% B, 6-12 min 90\% B, with a linear increase of B between 2 and $6 \mathrm{~min}$ and a 5 -min post run at $30 \% \mathrm{~B}$. The injection volume was $10 \mu \mathrm{L}$; flow was $0.5 \mathrm{~mL} / \mathrm{min}$; column temperature was $40^{\circ} \mathrm{C}$. The LC-MS/MS was operated in positive mode with an electrospray ionization source, and nitrogen was used as the drying and collision gas. For each compound, two transitions were monitored in Multiple Reaction Monitoring (MRM) mode. The first quadrupole was operated in unit mode; the second quadrupole was operated in the widest mode. The dwell time was $50 \mathrm{~ms}$. MS/MS settings for each compound were as in Faassen and Lurling [68]. Calibration standards were obtained from DHI LAB Products (Hørsholm, Denmark) and prepared in methanol. Samples were quantified against a calibration curve, and filter extracts were subsequently corrected for recovery. Each sample was injected once. Information on recovery, repeatability, limit of detection and limit of quantification of the analysis is given in [68].

\subsection{Statistical Analysis}

The chlorophyll- $a$ concentrations, photosystem II efficiencies and particle concentrations were statistically evaluated by repeated measure ANOVAs in the tool pack SPSS (version 19.0, IBM statistics, Armonk, NY, USA). Homogeneous subgroups were defined by a Tukey post hoc comparison at

$p<0.05$. The data were checked for normality using quantile-quantile (Q-Q) plots. In case Mauchly's test indicated that the assumption of sphericity had been violated, the degrees of freedom were corrected using Greenhouse-Geisser estimates of sphericity if epsilon $<0.75$ or applying the Huynh-Feldt correction if epsilon $>0.75$.

Total MC concentrations were evaluated statistically running one-way ANOVAs in the peroxide experiment and by $t$-ests in the ultrasound experiment using the toolpack, SigmaPlot version 12.3 (Systat Software, Inc., San Jose, CA, USA). The composition of both the dissolved and the particulate $\mathrm{MC}$ pools at the start and at the end of the peroxide experiment was evaluated by two-way ANOVAs in SigmaPlot with dissolved/particulate and peroxide concentration as fixed factors. Data were checked for normality and heteroscedasticity by the normality test (Shapiro-Wilk) and the equal variance test in SigmaPlot prior to executing ANOVA. The ANOVAs were followed by pairwise multiple comparison procedures (Holm-Sidak method) to distinguish means that were significantly different $(p<0.05)$. In the ultrasound experiment, the relative contribution of each $\mathrm{MC}$ variant in the dissolved and particulate MC pools in controls and ultrasound exposures was evaluated over time running two-way repeated measures ANOVAs in SPSS (version 19.0, IBM statistics, Armonk, NY, USA).

\section{Conclusions}

Hydrogen peroxide at concentrations of 4 and $8 \mathrm{mg} \mathrm{L}^{-1}$ effectively killed $M$. aeruginosa, but caused substantial release of MCs into the water. About $23 \%$ of the total MCs was removed by these hydrogen peroxide doses. To eliminate most MCs from the water, much higher $\mathrm{H}_{2} \mathrm{O}_{2}$ concentrations will be needed, which might strongly impair non-targeted organisms, such as the grazer, Daphnia magna.

The application of ultrasound had no water clearing effect; it caused a minimal growth inhibition and some release of MCs into the water. Ultrasound from commercial transducers is ineffective at controlling cyanobacteria in surface waters. 
The MC composition of the particulate and the dissolved fraction differed. The more hydrophobic variants, MC-LW and MC-LF, were underrepresented in the dissolved fraction of healthy cells. When cells were lysed, more hydrophobic variants appeared in the dissolved pool, but their abundance was still lower than in the particulate pool.

\section{Acknowledgments}

We thank Wendy Beekman for assistance during the experiment. E.J.F. was supported by Grant 817.02.019 from the Netherlands Organization for Scientific Research.

\section{Author Contributions}

M.L. designed the experiment, analyzed the data and wrote the manuscript. D.M. performed the experiment. E.J.F. analyzed the data and wrote the manuscript.

\section{Conflicts of Interest}

The authors declare no conflict of interest.

\section{References}

1. Smith, V.H.; Tilman, G.D.; Nekola, J.C. Eutrophication: Impacts of excess nutrient inputs on freshwater, marine, and terrestrial ecosystems. Environ. Pollut. 1999, 100, 179-196.

2. Paerl, H. Nutrient and other environmental controls of harmful cyanobacterial blooms along the freshwater-marine continuum. In Cyanobacterial Harmful Algal Blooms: State of the Science and Research Needs; Springer: New York, NY, USA, 2008; Volume 619, pp. 217-237.

3. Paerl, H.W.; Huisman, J. Blooms like it hot. Science 2008, 320, 57-58.

4. Merel, S.; Walker, D.; Chicana, R.; Snyder, S.; Baurès, E.; Thomas, O. State of knowledge and concerns on cyanobacterial blooms and cyanotoxins. Environ. Int. 2013, 59, 303-327.

5. Steffensen, D.A. Economic cost of cyanobacterial blooms. In Cyanobacterial Harmful Algal Blooms: State of the Science and Research Needs; Springer: New York, NY, USA, 2008; Volume 619, pp. 855-865.

6. Mackay, E.B.; Maberly, S.C.; Pan, G.; Reitzel, K.; Bruere, A.; Corker, N.; Douglas, G.; Egemose, S.; Hamilton, D.; Hatton-Ellis, T.; et al. Geoengineering in lakes: Welcome attraction or fatal distraction? Inland Waters 2014, 4, 349-356.

7. Jančula, D.; Maršálek, B. Critical review of actually available chemical compounds for prevention and management of cyanobacterial blooms. Chemosphere 2011, 85, 1415-1422.

8. Codd, G.A. Cyanobacterial toxins, the perception of water quality, and the prioritisation of eutrophication control. Ecol. Eng. 2000, 16, 51-60.

9. Codd, G.A.; Morrison, L.F.; Metcalf, J.S. Cyanobacterial toxins: Risk management for health protection. Toxicol. Appl. Pharmacol. 2005, 203, 264-272.

10. Funari, E.; Testai, E. Human health risk assessment related to cyanotoxins exposure. Crit. Rev. Toxicol. 2008, 38, 97-125. 
11. Lam, A.K.Y.; Prepas, E.E.; Spink, D.; Hrudey, S.E. Chemical control of hepatotoxic phytoplankton blooms: Implications for human health. Water Res. 1995, 29, 1845-1854.

12. Steffensen, D.; Burch, M.; Nicholson, B.; Drikas, B. Management of toxic blue-green algae (cyanobacteria) in Australia. Environ. Toxicol. 1999, 14, 183-195.

13. Kenefick, S.L.; Hrudey, S.E.; Peterson, H.G.; Prepas, E.E. Toxin release from Microcystis aeruginosa after chemical treatment. Water Sci. Technol. 1993, 27, 433-440.

14. Drábková, M.; Maršálek, B.; Admiraal, W. Photodynamic therapy against cyanobacteria. Environ. Toxicol. 2007, 22, 112-115.

15. Matthijs, H.C.P.; Visser, P.M.; Reeze, B.; Meeuse, J.; Slot, P.C.; Wijn, G.; Talens, R.; Huisman, J. Selective suppression of harmful cyanobacteria in an entire lake with hydrogen peroxide. Water Res. 2012, 46, 1460-1472.

16. Russell, A.D. Similarities and differences in the responses of microorganisms to biocides. J. Antimicrob. Chemother. 2003, 52, 750-763.

17. Wu, X.; Joyce, E.M.; Mason, T.J. The effects of ultrasound on cyanobacteria. Harmful Algae 2011, 10, 738-743.

18. Rajasekhar, P.; Fan, L.; Nguyen, T.; Roddick, F.A. A review of the use of sonication to control cyanobacterial blooms. Water Res. 2012, 46, 4319-4329.

19. Lürling, M.; Tolman, Y. Beating the blues: Is there any music in fighting cyanobacteria with ultrasound? Water Res. 2014, 66, 361-373.

20. Rajasekhar, P.; Fan, L.; Nguyen, T.; Roddick, F.A. Impact of sonication at $20 \mathrm{kHz}$ on Microcystis aeruginosa, Anabaena circinalis and Chlorella sp. Water Res. 2012, 46, 1473-1481.

21. Ma, B.; Chen, Y.; Hao, H.; Wu, M.; Wang, B.; Lv, H.; Zhang, G. Influence of ultrasonic field on microcystins produced by bloom-forming algae. Colloids Surf. B 2005, 41, 197-201.

22. Song, W.; De La Cruz, A.; Rein, K.; O'Shea, K. Ultrasonically induced degradation of microcystin-LR and -RR: Identification of products, effect of $\mathrm{pH}$, formation and destruction ofperoxides. Environ. Sci. Technol. 2006, 40, 3941-3946.

23. Chorus, I.; Bartram, J. Toxic Cyanobacteria in Water: A Guide to Their Public Health Consequences, Monitoring and Management; EandFN Spon: London, UK, 1999.

24. De Figueirdo, D.R.; Azeiteiro, U.M.; Esteves, S.M.; Gonçalves, F.J.M.; Pereira, M.J. Microcystin-producing blooms - A serious global public health issue. Ecotoxicol. Environ. Saf. 2004, 59, 151-163.

25. O’Neil, J.M.; Davis, T.W.; Burford, M.A.; Gobler, C.J. The rise of harmful cyanobacteria blooms: The potential roles of eutrophication and climate change. Harmful Algae 2012, 14, 313-334.

26. Doekel, S.; Marahiel, M.A. Biosynthesis of natural products on modular peptide synthetases. Metab. Eng. 2001, 3, 64-77.

27. Dittmann, E.; Fewer, D.P.; Neilan, B.A. Cyanobacterial toxins: Biosynthetic routes and evolutionary roots. FEMS Microbiol. Rev. 2013, 37, 23-43.

28. Zurawell, R.W.; Chen, H.; Burke, J.M.; Prepas, E.E. Hepatotoxic cyanobacteria: A review of the biological importance of microcystins in freshwater environments. J. Toxicol. Environ. Health 2005, 8, 1-37. 
29. Barrington, D.J.; Reichwaldt, E.S.; Ghadouani, A. The use of hydrogen peroxide to remove cyanobacteria and microcystins from waste stabilization ponds and hypereutrophic systems. Ecol. Eng. 2013, 50, 86-94.

30. Fan, J.; Peter Hobson, P.; Ho, L.; Daly, R.; Brookes, J. The effects of various control and water treatment processes on the membrane integrity and toxin fate of cyanobacteria. J. Hazard. Mater. 2014, 264, 313-322.

31. Drábková, M.; Admiraal, W.; Maršálek, B. Combined exposure to hydrogen peroxide and light: Selective effects on cyanobacteria, green algae, and diatoms. Environ. Sci. Technol. 2007, 41, 309-314.

32. Drábková, M.; Matthijs, H.C.P.; Admiraal, W.; Maršálek, B. Selective effects of $\mathrm{H}_{2} \mathrm{O}_{2}$ on cyanobacterial photosynthesis. Photosynthetica 2007, 45, 363-369.

33. Barrington, D.J.; Ghadouani, A.; Ivey, G.H. Cyanobacterial and microcystins dynamics following the application of hydrogen peroxide to waste stabilisation ponds. Hydrol. Earth Syst. Sci. 2013, 17, 2097-2105.

34. Wang, Z.; Li, D.; Qin, H.; Li, Y. An integrated method for removal of harmful cyanobacterial blooms in eutrophic lakes. Environ. Pollut. 2012, 160, 34-41.

35. Worm, J.; Søndergaard, M. Dynamics of heterotrophic bacteria attached to Microcystis spp. (Cyanobacteria). Aquat. Microb. Ecol. 1998, 14, 19-28.

36. Geng, L.; Qin, B.; Yang, Z. Unicellular Microcystis aeruginosa cannot revert back to colonial form after short-term exposure to natural conditions. Biochem. Syst. Ecol. 2013, 51, 104-108.

37. Reichwaldt, E.S.; Zheng, L.; Barrington, D.J.; Ghadouani, A. Acute toxicological response of Daphnia and Moina to hydrogen peroxide. J. Environ. Eng. 2012, 138, 607-611.

38. Mikula, P.; Zezulka, S.; Jančula, D.; Maršálek, B. Metabolic activity and membrane integrity changes in Microcystis aeruginosa-New findings on hydrogen peroxide toxicity in cyanobacteria. Eur. J. Phycol. 2012, 47, 195-206.

39. Fan, J.; Ho, L.; Hobson, P.; Brookes, J. Evaluating the effectiveness of copper sulphate, chlorine, potassium permanganate, hydrogen peroxide and ozone on cyanobacterial cell integrity. Water Res. 2013, 47, 5153-5164.

40. Berg, K.; Skulberg, O.M.; Skulberg, R. Effects of decaying toxic blue-green algae on water quality-A laboratory study. Arch. Hydrobiol. 1987, 108, 549-563.

41. Rivasseu, C.; Martins, S.; Hennion, M.-C. Determination of some physicochemical parameters of microcystins (cyanobacterial toxins) and trace level analysis in environmental samples using liquid chromatography. J. Chromatogr. A 1998, 799, 155-169.

42. Codd, G.; Bell, S.; Kaya, K.; Ward, C.; Beattie, K.; Metcalf, J. Cyanobacterial toxins, exposure routes and human health. Eur. J. Phycol. 1999, 34, 405-415.

43. Tonk, L.; Visser, P.M.; Christiansen, G.; Dittmann, E.; Snelder, E.O.F.M.; Wiedner, C.; Mur, L.R.; Huisman, J. The microcystin composition of the cyanobacterium Planktothrix agardhii changes toward a more toxic variant with increasing light intensity. Appl. Environ. Microbiol. 2005, 71, 5177-5181.

44. Robillot, C.; Vinh, J.; Puiseux-Dao, S.; Hennion, M.-C. Hepatotoxin production kinetics of the cyanobacterium Microcystis aeruginosa PCC 7820, as determined by HPLC-mass spectrometry and protein phosphatase bioassay. Environ. Sci. Technol. 2000, 34, 3372-3378. 
45. Vesterkvist, P.S.M.; Meriluoto, J.A.O. Interaction between microcystins of different hydrophobicities and lipid monolayers. Toxicon 2003, 41, 349-355.

46. Ríos, V.; Moreno, I.; Prieto, A.I.; Soria-Díaz, M.E.; Frías, J.E.; Cameán, A.M. Comparison of Microcystis aeruginosa (PCC 7820 and PCC 7806) growth and intracellular microcystins contentdetermined by liquid chromatography-mass spectrometry, enzyme-linked immunosorbent assay anti-Adda and phosphatase bioassay. J. Water Health 2014, 12, 69-80.

47. Pavagadhi, S.; Gong, Z.; Hande, M.P.; Dionysiou, D.D.; de la Cruz, A.A.; Balasubramanian, R. Biochemical response of diverse organs in adult Danio rerio (zebrafish) exposed to sub-lethal concentrations of microcystin-LR and microcystin-RR: A balneation study. Aquat. Toxicol. 2012, 109, 1-10.

48. Flexidal Technics. Avaliable online: http://flexidal.be/nl/produktenvanflexidal_algen.asp? rubriek=algenandfotoid $=8$ (accessed on 26 September 2014).

49. Lürling, M.; Tolman, Y. Effects of commercially available ultrasound on the zooplankton grazer Daphnia and consequent water greening. Water 2014, 6, 3247-3263.

50. Neppiras, E.A. Acoustic cavitation. Phys. Rep. 1980, 61, 159-251.

51. Hoyer, O.; Clasen, J. The application of new technologies in the water treatment process of a modern waterworks. Water Sci. Technol. 2002, 2, 63-69.

52. Holm, E.R.; Stamper, D.M.; Brizzolara, R.A.; Barnes, L.; Deamer, N.; Burkholder, J.M. Sonication of bacteria, phytoplankton and zooplankton: Application to treatment of ballast water. Mar. Pollut. Bull. 2008, 56, 1201-1208.

53. Miller, D.L. A review of the ultrasonic bioeffects of microsonation, gas-body activation, and related cavitation-like phenomena. Ultrasound Med. Biol. 1987, 13, 443-470.

54. Purcell, D. Control of Algal Growth in Reservoirs with Ultrasound. Ph.D. Thesis, Cranfield University, Bedfordshire, UK, December 2009.

55. Waajen, G.W.A.M.; Faassen, E.J.; Lürling, M. Eutrophic urban ponds suffer from cyanobacterial blooms: Dutch examples. Environ. Sci. Pollut. Res. 2014, doi:10.1007/s11356-014-2948-y.

56. Borics, G.; Grigorszky, G.; Szabó, S.; Padisák, J. Phytoplankton associations in a small hypertrophic fishpond in East Hungary during a change from bottom-up to top-down control. Hydrobiologia 2000, 424, 79-90.

57. Yokohama, A.; Park, H.-D. Mechanism and prediction for contamination of freshwater bivalves (unionidae) with the cyanobacterial toxin microcystin in hypereutrophic Lake Suwa, Japan. Environ. Toxicol. 2002, 17, 424-433.

58. Hirose, M.; Nishibe, Y.; Ueki, M.; Nakano, S. Seasonal changes in the abundance of autotrophic picoplankton and some environmental factors in hypereutrophic Furuike Pond. Aquat. Ecol. 2003, 37, 37-43.

59. Fairchild, W.; Anderson, J.M.; Velinsky, D.J. The trophic state 'chain of relationships' in ponds: Does size matter? Hydrobiologia 2005, 539, 35-46.

60. Bauzá, L.; Aguilera, A.; Echenique, R.; Andrinolo, D.; Giannuzzi, L. Application of hydrogen peroxide to the control of eutrophic lake systems in laboratory assays. Toxins 2014, 6, 2657-2675.

61. Govaert, E.; Vanderstukken, M.; Muylaert, K. Evaluatie Van Effecten Van Ultrasone Straling Op Het Ecosysteem; Katholieke Universiteit Leuven: Kortrijk, Belgium, 2007. (In Dutch) 
62. Kardinaal, E.; De Haan, M.; Ruiter, H. Maatregelen ter voorkoming blauwalgen werken onvoldoende. $\mathrm{H}_{2} \mathrm{O}$ 2008, 7, 4-7. (In Dutch)

63. Li, L.; Pan, G. A universal method for flocculating harmful algal blooms in marine and fresh waters using modified sand. Environ. Sci. Technol. 2013, 47, 4555-4562.

64. Lürling, M.; Van Oosterhout, F. Controlling eutrophication by combined bloom precipitation and sediment phosphorus inactivation. Water Res. 2013, 47, 6527-6537.

65. Drikas, M.; Chow, C.W.K.; House, J.; Burch, M.D. Using coagulation, and settling to remove toxic cyanobacteria. J. Am. Water Works Ass. 2001, 93, 100-111.

66. Chow, C.W.K.; Drikas, M.; House, J.; Burch, M.D.; Velzeboer, R.M.A. The impact of conventional water treatment processes on cells of the cyanobacterium Microcystis aeruginosa. Water Res. 1999, 33, 3253-3262.

67. Lürling, M.; Beekman, W. Palmelloids formation in Chlamydomonas reinhardtii: Defence against rotifer predators? Ann. Limnol. 2006, 42, 65-72.

68. Lürling, M.; Faassen, E.J. Dog poisonings associated with a Microcystis aeruginosa bloom in the Netherlands. Toxins 2013, 5, 556-567.

(C) 2014 by the authors; licensee MDPI, Basel, Switzerland. This article is an open access article distributed under the terms and conditions of the Creative Commons Attribution license (http://creativecommons.org/licenses/by/4.0/). 